\title{
Falls of elderly people living in rural areas: prevalence and associated factors
}

\author{
Quedas de idosos residentes na zona rural: prevalência e fatores associados \\ Caídas en ancianos residentes en el campo: prevalencia y factores asociados
}

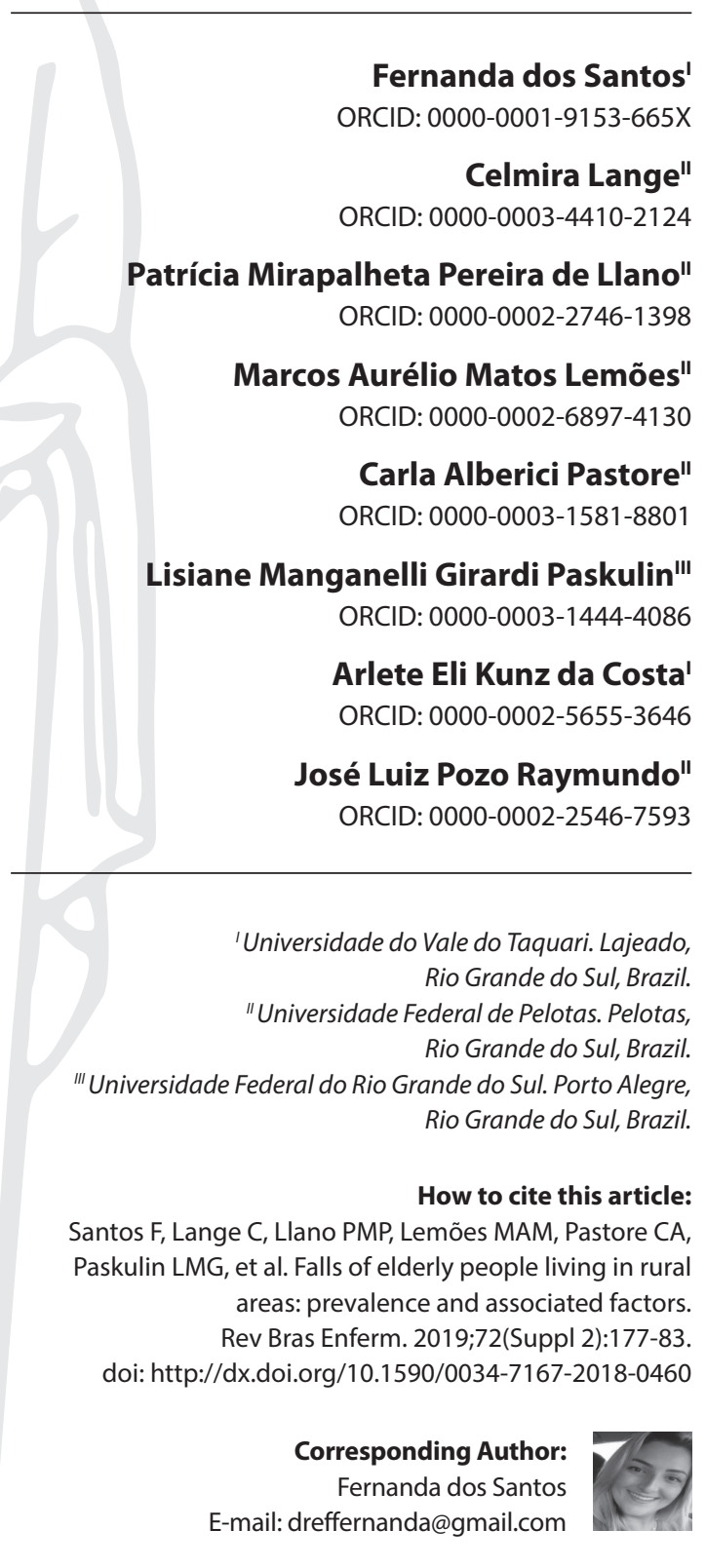

Submission: 06-04-2018 Approval: 04-25-2019

\begin{abstract}
Objective: to identify the prevalence and factors associated with falls in the elderly population living in rural areas. Method: this is a cross-sectional study, carried out in 2014, with 820 older adults recorded in the Family Health Strategy (Estratégia Saúde da Familia). The association between the reporting of falls in 12 months and their associated factors was verified by the Chi-square and Fischer's exact tests and by multivariate logistic regression analysis. Results: the majority of the sample was female (56.1\%), white (90.2\%) and aged 60-69 years (54.9\%). The prevalence of falls was $27.9 \%$, and being female, hypertensive and diabetic was associated to falls. Conclusion: it is the responsibility of health professionals to have a closer look at the elderly who have these chronic diseases, especially within the scope of the Family Health Strategy, which works longitudinally with these patients, in addition to improving nursing care aimed at this population.

Descriptors: Rural Health; Aged; Accidental Falls; Nursing Care.
\end{abstract}

\section{RESUMO}

Objetivo: identificar a prevalência e os fatores associados a quedas na população idosa residente em zona rural. Método: estudo transversal, realizado no ano de 2014, com 820 idosos cadastrados na Estratégia Saúde da Família. A associação entre o relato de quedas em 12 meses e seus fatores associados foi verificada pelos testes qui-quadrado, exato de Fischer e análise multivariada por meio de regressão logística. Resultados: a maior parte da amostra era do sexo feminino $(56,1 \%)$, de pele branca $(90,2 \%)$ e faixa etária de $60-69$ anos (54,9\%). A prevalência de quedas foi de $27,9 \%$, sendo as variáveis sexo feminino, ser hipertenso e diabético associadas às quedas. Conclusão: compete aos profissionais da saúde ter um olhar mais atento sobre os idosos que apresentam essas doenças crônicas, especialmente no âmbito da Estratégia de Saúde da Família, que trabalha de forma longitudinal com esses pacientes, além de aperfeiçoar os cuidados de enfermagem voltados para atendimento a essa população.

Descritores: Saúde da População Rural; Idoso; Acidentes por Quedas; Cuidados de Enfermagem; Perfil de Saúde.

\section{RESUMEN}

Objetivo: identificar la prevalencia y los factores asociados con las caídas en la población anciana residente en el campo. Método: estudio transversal, realizado en el 2014 con 820 ancianos registrados en la Estrategia de Salud de la Familia. La asociación entre el reporte de caídas en los últimos 12 meses y sus factores asociados se verificó por medio de la prueba chi-cuadrado, del test exacto de Fischer y del análisis multivariante con regresión logística. Resultados: la mayor parte de la muestra era del sexo femenino $(56,1 \%)$, de piel blanca $(90,2 \%)$ y grupo de edad de entre $60-69$ años (54,9\%). La prevalencia de caídas fue del $27,9 \%$, siendo que las variables sexo femenino, ser hipertenso y diabético estuvieron asociadas a las caídas. Conclusión: a los profesionales de salud les hace necesario mirar más detenidamente los ancianos que presentan estas enfermedades crónicas, especialmente en el marco de la Estrategia de Salud de la Familia, que trabaja de forma longitudinal con esos pacientes, además mejorar los cuidados de enfermería durante la atención a esa población.

Descriptores: Salud Rural; Anciano; Accidentes por Caídas; Atención de Enfermería; Perfil de Salud. 
Falls of elderly people living in rural areas: prevalence and associated factors Santos F, Lange C, Llano PMP, Lemões MAM, Pastore CA, Paskulin LMG, et al.

\section{INTRODUCTION}

With the aging process, the human body goes into physiological decline, culminating with decreased bone density and muscle mass, postural instability, impaired visual and auditory capacity, and increased drug consumption. These changes, isolated or associated to environmental risks, may predispose the individual to fall, a sentinel event in the life of elderly people, reducing functional capacity. Elderly falls are considered one of the most disabling and worrying geriatric syndromes, since a single event can have repercussions in the social, economic and health sphere ${ }^{(1)}$.

The fall, an unintended event that results in the change of the initial position of the individual to the same level or to a lower level ${ }^{(2)}$, has its prevalence altered according to the characteristics of the studied elderly population-ranging from 10.7 to $32.1 \%$ for the elderly living in the community, since, in institutionalized older adults, that is, residents of long-term institutions, this number increases $(66.7 \%)^{(3-8)}$. These data reveal the vulnerability to which elderly people are exposed ${ }^{(7-8)}$.

The etiology of the fall is usually multifactorial, resulting from the interaction between predisposing and precipitating factors, which may be intrinsic and extrinsic ${ }^{(9)}$. Being a woman, advanced age, the presence of two or more diseases and depressive symptoms stand out as important factors triggering this event among the elderly ${ }^{(10-11)}$. Regarding the extrinsic factors, such as type of housing, low illumination, non-adherent carpets, high steps, daytime period, these are characteristics of the elderly population suffering from falls $s^{(12-13)}$.

Falls represented the most frequent problem when compared to other external causes that affect the elderly, according to an investigation that aimed to identify scientific productions that addressed the most frequent external causes and their consequences in the care of the elderly in emergency services in some places in Brazil(14).

Although the human aging process in urban and rural areas is similar, a number of particularities should be noted. Sukumar et al. ${ }^{(15)}$ conducted a study that investigated the influence of geographic location and the results of fall-related injuries in older adults. The results showed that, between 2003 and 2012, rural residents were less hospitalized and there was a lower growth of hospitalization rates compared to urban residents. Rural residents had a shorter total hospitalization time, a higher readmission rate within 28 days after discharge, and a higher mortality rate within 30 days of hospitalization ${ }^{(15)}$.

The population that inhabits the rural area shows peculiarities due to its culture, ways of life, work and other factors. An example of this is in the social activity of the elderly in the urban zone: they organize themselves in the form of a network, they practice physical activities, they make handicrafts, they participate in gymnastics, dances, and other cultural activities. On the other hand, in rural areas, the elderly enjoy their leisure by attending church, religious events, visiting relatives or neighbors ${ }^{(16)}$.

In this sense, it is relevant to know, through scientific research, the elderly population beyond urban space, as well as those who suffered falls. However, population aging is dynamic, that is, every human being ages in a way; therefore, all forms of research are important in this population and in all contexts.

\section{OBJECTIVE}

To identify the prevalence and factors associated with falls in the elderly population living in rural areas.

\section{METHOD}

\section{Ethical aspects}

This study is part of a project titled "Prevalência e fatores associados à Síndrome da Fragilidade na população idosa" (Prevalence and factors associated with Frailty Syndrome in the elderly population). The research was approved by the Research Ethics Committee (REC) of the Federal University of Pelotas (UFPel) on May 19, 2014 and followed the principles of the Resolution of the National Health Council no. 466/12 $2^{(17)}$. When following the precepts of the REC, the Informed Consent Form (TCLE) was obtained, which was signed by the study coordinator and the elderly person, in two copies, and, if this was not possible, it was signed by a substitute respondent/relative, being one copy for the participant and the other for the interviewer.

\section{Design, location of the study and study period}

This is a cross-sectional study with the elderly population who lives in the rural area of the municipality of Pelotas, in the Southern region of Rio Grande do Sul. The municipality of Pelotas had 51 primary health units (UBS), being 12 located in the rural area, of which 10 had the Estratégia Saúde da Família modality (ESF - Family Health Strategy). Data collection was developed from July to November 2014.

\section{Sample and inclusion and exclusion criteria}

The population of the study was composed of elderly individuals 60 years of age or older, linked to the microareas of the ESFs that comprise the rural area of the municipality of Pelotas (RS), randomly drawn by medical records. To get the required number of seniors, a list was organized per ESF containing their name, age and address. It should be noted that the number of older adults selected per UBS was proportional to the number of elderly people enrolled in each one.

\section{Study protocol}

The following parameters and estimates were used to calculate the sample of the main study: population size of 328,275 individuals in the municipality of Pelotas ${ }^{(18)}, 95 \%$ confidence level, estimated prevalence of frailty in the elderly of $19.9 \%{ }^{(19)}$ and an acceptable error of $3 \%$. With these parameters, the initial calculation basis of the elderly was 680 , added to $10 \%$ of losses and refusals and $10 \%$ for the control of confounding factors, totaling 823 older adults. For this research, 834 elderly people were randomly selected, of which 820 were interviewed.

The dependent variable in this study was the occurrence of a fall in the last year. The definition of fall used as an outcome was: "inadvertently coming to rest on the ground, floor or other lower level, excluding intentional change in position to rest in furniture, 
wall or other objects"(20). The question used for the outcome was: "Have you suffered a fall in the last 12 months (last year)?". The independent variables were: socioeconomic, environmental and demographic data, and health problems.

At the end of the collection, the questionnaires were entered in the Epi Info $6.05 \mathrm{~d}$. The data were double typed by independent typists, in which all the information obtained was inserted, creating two databases. These were analyzed for consistency, and the errors were corrected through physical questionnaires until reaching $100 \%$ of agreement between the typings.

The following inclusion criteria were listed in the study: being 60 years old or over, living in the rural area of Pelotas (RS), having been included in the draw by the researchers and accepting disclosure of the data. Those individuals who, at the time of the interview, were traveling, deprived of their liberty by judicial decision, residing in long-term institutions, or hospitalized during the period of data collection in that locality were excluded.

\section{Study protocol}

The collection team consisted of ten people, being five postgraduate students and five nursing academics of the School of Nursing of the UFPel, these were eligible after selection. After this stage, there was a training with the intention of approaching the members, explaining the objectives, showing the importance of the research to the elderly population and also showing the study questionnaire. In order to improve logistics and data collection instruments, a pilot study was conducted by undergraduate and graduate students. It should be noted that these questionnaires were not part of the final data.

This step was fundamental to the last adjustments of the definitive instrument, as well as to the preparation of the field manual, which aimed to standardize the way of collecting data among the interviewers. The field manual covered the general instructions for data collection: guidance on approaching the elderly, about the questions and the application of tests, which needed patience and time from the interviewers.

After the qualification of the interviewers, each received a data collection kit formed by identification of the collector/interviewer, folder, field manual, pencil, pen, eraser and sharpener; the collection instruments, as well as the ICFs, were printed in two copies. In addition, the materials necessary for the Mini-Mental State Exam test were prepared, such as A4 blank sheet, and a sheet with the words "Close your eyes."

Aiming to know the scenario of the study, the post-graduate students and the counselor visited the ESFs that were part of the research. At that time, help of the community health agents (ACS - Agentes Comunitários de Saúde) was requested in the location of the households of the selected elderly people and in the transmission of the research to this population. In order to avoid the resistance or even the fear of the elderly in receiving the interviewers in their residence, the data collection was disseminated in the local media, in the community radio, by the priest in the masses and in trading houses. With the knowledge of the research scenario, training of the interviewers, field manual and questionnaire ready, as well as with all the authorizations granted, data collection started.
For a better organization of the investigation, each post-graduate was responsible for an activity, such as instrument printing and ICF, annotation and control of the distributed questionnaires, receiving the completed ones and reviewing them, organization of the cash book, as well as the time and place of boarding, among other tasks that are important in carrying out an organized work.

\section{Analysis of results and statistics}

Data analysis was conducted in the STATA 11.1 software. After checking for inconsistencies, analysis was performed to characterize the sample. In the descriptive statistics, the absolute frequency ( $n$ ) and the relative frequency (\%) were included. In addition, in order to investigate the association between the variables composing the profile of the elderly and fall, statistical tests were performed, and the bivariate analysis was conducted using the Chi-square and Fischer's exact tests for independent samples, with a confidence level of $95 \%$. Hierarchical multivariate analysis was performed through logistic regression.

\section{RESULTS}

834 elderly people were randomly selected in this study, of which nine refused to participate even after two attempts, and five were not found after five attempts, resulting in a total of 820 respondents at the end of the study. Almost all of the elderly answered the questionnaire (95.5\%), while six questionnaires were answered, in part, by a substitute respondent/family member, because the elderly had cognitive decline, but, in any case, it was the older adult who answered the tests.

In this study, there was a predominance of the female sex (56.1\%), white skin $(90.2 \%)$, elderly living with a significant other $(71.5 \%)$ and in the age group of $60-69$ years (54.9\%). The youngest adult was 60 years old, and the oldest 95 years old, the average age being 70.0 years (SD: 7.6 years). Regarding schooling, described in years of study, it was evidenced that $5.6 \%$ of the elderly had eight years of schooling or more, and $15.2 \%$ were illiterate. The mean was 4.0 years of study (SD: 2.4 years), in which the minimum of years was zero, and the maximum was 23 years. Only $9.0 \%$ reported living alone, and, of the $91.0 \%$ who did not live alone, $46.3 \%$ lived with their children.

When asked if they used to stay home alone for a period of time, $64.1 \%$ reported never or rarely being alone at home, while $16.8 \%$ remained alone at home for a period longer than 12 hours. Of the elderly interviewed, $92.0 \%$ were retired, and of these, $64.5 \%$ still worked, the majority being in agriculture.

In this study, the majority of the elderly who suffered falls were female (62.0\%): the probability of falling was $40.0 \%$ higher in relation to the opposite sex, that is, 1.4 times higher than in the men.

Table 1 shows the socioeconomic and demographic variables of the elderly who fell and who did not fall.

Data on behavioral habits showed that, in relation to exposure to smoking, $89.5 \%$ did not smoke and $27.9 \%$ were ex-smokers. Among smokers, the prevalence of falls was $9.2 \%$. Regarding alcohol intake, $66.1 \%$ did not consume it and $12.2 \%$ did so on a daily basis; $28.8 \%$ of the elderly who reported drinking alcoholic beverages suffered a fall in 12 months. 
Table 1 - Bivariate analysis between falls and demographic and socioeconomic variables, Pelotas, Rio Grande do Sul, Brazil, $2014(\mathrm{~N}=820)$

\begin{tabular}{|c|c|c|c|}
\hline \multirow[b]{2}{*}{$\begin{array}{l}\text { Demographic and } \\
\text { socioeconomic variables }\end{array}$} & \multicolumn{2}{|c|}{ Fall } & \multirow[b]{2}{*}{$p$ value } \\
\hline & $\begin{array}{l}\text { Yes } \\
\text { n (\%) }\end{array}$ & $\begin{array}{c}\text { No } \\
n(\%)\end{array}$ & \\
\hline Sex & & & $0.034^{*}$ \\
\hline Female & $142(62.0)$ & $318(53.8)$ & \\
\hline Male & $87(38.0)$ & $273(46.2)$ & \\
\hline Age group (years) $(n=819)$ & & & $0.729 *$ \\
\hline $60-69$ & $127(55.5)$ & $323(54.8)$ & \\
\hline $70-79$ & $76(33.2)$ & $193(32.7)$ & \\
\hline $80-89$ & $25(10.9)$ & $65(11.0)$ & \\
\hline 90 or more & $1(0.4)$ & $9(1.5)$ & \\
\hline Marital status & & & $0.187^{*}$ \\
\hline Has a significant other & $156(68.1)$ & $430(72.8)$ & \\
\hline Does not have a significant other & $73(31.9)$ & $161(27.2)$ & \\
\hline Lives alone & & & $0.239^{*}$ \\
\hline No & $204(89.1)$ & $542(91.7)$ & \\
\hline Yes & $25(10.9)$ & $49(8.3)$ & \\
\hline Schooling (years of study) & & & $0.228^{*}$ \\
\hline Illiterate & $29(12.8)$ & $82(14.0)$ & \\
\hline $1-3$ & $87(38.3)$ & $183(31.2)$ & \\
\hline $4-7$ & 95 (41.9) & $284(48.5)$ & \\
\hline$\geq 8$ & $16(7.1)$ & $37(6.3)$ & \\
\hline Has a job & & & $0.595^{*}$ \\
\hline Yes & $213(36.0)$ & $78(34.1)$ & \\
\hline No & $378(64.0)$ & $151(65.9)$ & \\
\hline Per capita income (minimum wage) & & & $0.933^{* *}$ \\
\hline$<1$ & $2(0.9)$ & $7(1.2)$ & \\
\hline $1-2$ & $186(81.2)$ & $467(79.7)$ & \\
\hline$\geq 2$ & $41(17.9)$ & $112(19.1)$ & \\
\hline
\end{tabular}

Note: * $p$ value by the Chi-square test; ${ }^{* *} p$ value by the Fisher's exact test.

Table 2 - Bivariate analysis between falls and morbidity, Pelotas, Rio Grande do Sul, Brazil, 2014 ( $\mathrm{N}=820$ )

\begin{tabular}{lccc}
\hline Morbidity & \multicolumn{2}{c}{ Fall } & \\
& $\begin{array}{c}\text { Yes } \\
\mathbf{n}(\%)\end{array}$ & $\begin{array}{c}\text { No } \\
\mathbf{n}(\%)\end{array}$ & $\boldsymbol{p}$ value \\
\hline $\begin{array}{l}\text { Systemic arterial hypertension (SAH) } \\
\quad \text { Yes }\end{array}$ & $157(68.6)$ & $383(64.8)$ & $0.309^{*}$ \\
$\quad$ No & $72(31.4)$ & $208(35.2)$ & \\
$\begin{array}{l}\text { Diabetes mellitus (DM) } \\
\quad \text { Yes }\end{array}$ & $50(21.8)$ & $89(15.1)$ & $0.002^{*}$ \\
$\quad$ No & $179(78.17)$ & $502(84.9)$ & \\
$\begin{array}{l}\text { Rheumatism } \\
\quad \text { Yes }\end{array}$ & $78(34.1)$ & $152(25.7)$ & $0.017^{*}$ \\
$\quad$ No & $151(65.9)$ & $439(74.3)$ & \\
$\begin{array}{l}\text { Osteoporosis } \\
\quad \text { Yes }\end{array}$ & & $0.004^{*}$ \\
$\quad$ No & $52(22.7)$ & $85(14.4)$ & \\
$\begin{array}{l}\text { Cerebrovascular accident } \\
\text { Yes }\end{array}$ & $177(77.3)$ & $506(85.6)$ & \\
$\quad$ No & $25(10.9)$ & $46(7.8)$ & \\
\hline
\end{tabular}

Note: * $p$ valor by the Chi-square test; ** $p$ value by the Fisher's exact test.

Table 2 shows the diseases reported by the elderly in the study. In Table 3, it is possible to observe the multivariate analysis, using the Fisher's exact test and the association between the independent variables that obtained significance and the fall. The following factors were associated with falls: female gender (RP: 1.401; $\mathrm{p} \leq$ 0.016); having SAH (RR: 1.184; $\mathrm{p} \leq 0.023$ ) and having DM (RP: $1.576 ; p \leq 0.011$ ).

The prevalence rate of falls for diabetic elderly was 1.58 , that is, the probability of a DM patient falling is almost $60 \%$ higher in relation to the elderly without this morbidity. Regarding $\mathrm{SAH}$, the study showed that having this pathology increases the probability of falling by $18.0 \%$ in relation to who does not have it. The prevalence of falls was $27.9 \%$ in this study.

Table 3 - Multivariate analysis between fall of the elderly and associated variables, Pelotas, Rio Grande do Sul, Brazil, 2014 ( $N=820)$

\begin{tabular}{ccc}
\hline Variables & Prevalence ratio (PR) & $\boldsymbol{p}$ value \\
\hline Female sex & 1.401 & 0.016 \\
SAH & 1.184 & 0.023 \\
DM & 1.576 & 0.011 \\
\hline
\end{tabular}

Note: SAH - Systemic arterial hypertension; DM - Diabetes mellitus.

\section{DISCUSSION}

The prevalence of falls in this study reported by the elderly in the last 12 months was similar to that reported in other population-based studies in other regions of Brazil, but conducted in the urban area. It should be noted that the association of the falling event with the elderly population living in the rural area is not yet a frequent subject of study, which also highlights the importance of this investigation. A national investigation of a household survey with 729 elderly living in the urban area showed a prevalence of falls of $28.3 \%{ }^{(10)}$.

Carneiro et al. ${ }^{(21)}$ conducted a study with a sample of 683 non-institutionalized elderly people living in the municipality of Montes Claros, northern Minas Gerais, and observed a prevalence of falls of $28.4 \%$. On the other hand, a survey corroborated a $36.4 \%$ prevalence of falling episodes in 12 months $^{(22)}$. At the international level, this occurrence has fluctuations, since a prevalence of $23.0 \%$ was observed in a survey of elderly people in Nagasaki, Japan ${ }^{(23)}$. In contrast, a research with elderly people from Alabama, United States, showed a $47.0 \%$ prevalence of falls of the elderly ${ }^{(24)}$.

Being female, aged 60 to 69 years and living with a significant other were the majority among the elderly who suffered a fall. Studies have shown that being female is a risk factor for falls $\mathbf{s}^{(5,10,25)}$. The prevalence of elderly women in the context of aging is due to the higher life expectancy, being called feminization of old age.

However, regarding the higher prevalence of falls among women, there is still no definitive explanation about this fact; however, it is thought that lower quality and strength of muscle mass in women as well as the prevalence of chronic diseases may increase the likelihood of frailty in women ${ }^{(21)}$. It is important to point out that this study was developed in the rural area, however, frequently, its population is mostly male ${ }^{(26)}$, differing from the data of this research, in which there were more women than men.

Regarding the age group, the data of this research were consistent with a cross-sectional population-based study with elderly individuals aged 65 years or over living in urban areas ${ }^{(11)}$. On the other hand, there is a consensus in national and international literature about the prevalence of falls in older people, since with 
increasing age the senescence process causes progressive and functional changes ${ }^{(3,24,27)}$. A study conducted with elderly people living in rural areas showed that the majority were included in the age group of 60-69 years, but this survey was about the presence of chronic diseases among the individuals ${ }^{(28)}$.

This research, in Pelotas, confirmed the presence of accidents due to falls in the majority of younger seniors, a fact that may be associated with the study carried out by this population, which is more arduous and requires more resourcefulness as a result of irregular terrain, as well as the presence of chronic diseases. In the same way that long-lived elderly people in this study do not cover an expressive number of chronic diseases compared to the younger ones, consequently, they will suffer fewer falls, since falling was associated with the presence of SAH and DM in this study.

The marital situation was not associated with the fall event, corroborating a study developed with 683 non-institutionalized older people ${ }^{(21)}$. In both investigations, the population living with a partner was predominant, being married, in a stable union or with a significant other. There are few surveys that consider this variable.

It was observed that the chance of falling was higher among the elderly who did not live alone. On the other hand, living alone was a characteristic observed both for falls and recurrent falls in a study with 391 elderly residents in the community ${ }^{(11)}$, data that challenge the research in the rural area, in which the independent variable of living alone had no statistical inference on the event.

Elderly people with low schooling had a greater occurrence of falls in the bivariate analysis, although this association was not statistically significant in the final predictive model, which is consistent with a study performed by Cruz et al. ${ }^{(29)}$ with 462 non-institutionalized elderly individuals. A study performed with elderly living in the rural area of a municipality in the interior of Rio Grande do Sul also showed harmonic data with this research in the rural area of the municipality of Pelotas ${ }^{(28)}$.

The knowledge added to the greatest number of schooling years may be a protective factor for the presence of falls in the elderly, in the sense that the higher educational level exposes the elderly to the risk factors of diseases and accidents. For cultural or distance reasons, the rural population had less access to school, evidencing this reduction in years of schooling, and it was also cogent that the children help in farming, attending school less, thus leaving studies in second plan.

Regarding morbidity, systemic arterial hypertension and diabetes mellitus were still associated with the event in the multivariate analysis, according to studies on the subject in non-institutionalized urban population ${ }^{(9)}$. Focchesatto, Rockett and Perry ${ }^{(28)}$ studied 70 individuals aged 60 years or older residing in the rural area of Rio Grande do Sul, where systemic arterial hypertension, osteoporosis and dyslipidemia were the most reported diseases by the participants. Differently from this research, Carneiro et al. ${ }^{(21)}$ showed that some investigated diseases, although associated in a bivariate analysis, were not maintained in the final model.
The presence of chronic diseases in aging is a public health problem with high prevalence and important consequences, corroborating the finding in a study that investigated the prevalence and distribution of multimorbidity in Brazilian older people, in which only $6.0 \%$ of the sample did not show chronic disease. Concerning these diseases, $81.3 \%$ had two or more and $64.0 \%$ had three or more, demonstrating the challenges that health services and health professional training are facing ${ }^{(30)}$. This study concluded that multimorbidity was high in the elderly from Bagé-RS, compared to the percentages found in other countries, alerting public administrators about the importance of using the principles and guidelines of the Unified Health System in order to improve the health conditions of this population ${ }^{(30)}$, since more than half of the elderly interviewed were treated by the ESF, demonstrating the vulnerability of this service.

\section{Limitations of the study}

Despite the significant aspects related to the occurrence of falls in the elderly and associated factors identified in this study, we can not exclude the presence of recall bias as a limitation of the study. In the sense that those older people who suffered more severe falls may have more frequently remembered details than those who had only bruises, as well as remembering an event occurred 12 months ago may be underreported. In addition, the elderly credit their problems of balance and walking to ageing, so that mobility difficulties are not detected until a fall with a serious consequence occurs.

\section{Contributions to the field of nursing, health care or public policy}

Nursing, as a majority profession of the health services, plays a fundamental role in the evaluation of the elderly, as well as in the identification of older adults with risks of falling and presence of chronic diseases. Noticing the risk factors of the fall event, preventing them becomes an increasingly necessary practice within the professional care. It is worth emphasizing the premise that a preventive approach to the elderly falls event must be multisectoral, multiprofessional and multifactorial, through groups that approach accidents due to falls, as well as their causes and consequences in the life of the elderly.

\section{CONCLUSION}

It was concluded that older adults with the higher risk of falls were female, hypertensive and diabetic patients. The results evidenced in this research corroborate other studies already carried out in the urban area, however, the application of investigations in the rural area is opportune and indicated at this moment, considering the increase in life expectancy and the participation of the elderly in society. The data obtained allow guiding strategies of care to the elderly exposed to the event of fall in all contexts.

\section{REFERENCES}

1. Cavalcante ALP, Aguiar JB, Gurgel LA. Fall-related factors in elderly residents in Fortaleza, Ceará State, Brasil. Rev Bras Geriatr Gerontol [Internet]. 2012 [cited 2017 Oct 05];15(1):137-46. Available from: http://www.scielo.br/pdf/rbgg/v15n1/15.pdf 
Falls of elderly people living in rural areas: prevalence and associated factors Santos F, Lange C, Llano PMP, Lemões MAM, Pastore CA, Paskulin LMG, et al.

2. Gasparotto LPR, Falsarella GR, Coimbra AMV. Falls in elderly: basics concepts and updates of research in health. Rev Bras Geriatr Gerontol [Internet]. 2014 [cited 2017 Oct 03];17(1):201-9. Available from: http://www.scielo.br/pdf/rbgg/v17n1/1809-9823-rbgg-17-01-00201.pdf

3. Cevizci S, Uluocak S, Aslan C, Gökulu G, Bilir O, Bakar C. Prevalence of falls and associated risk factors among aged population: community based cross-sectional study from Turkey. Cent Eur J Public Health [Internet]. 2015 [cited 2017 Sep 06];23(3):233-9. Available from: http:// apps.szu.cz/svi/cejph/archiv/2015-3-10-full.pdf

4. Reis KMC, Jesus CAC. Coorte de idosos institucionalizados: fatores de risco para queda a partir do diagnóstico de enfermagem. Rev LatinoAm Enfermagem [Internet]. 2015 [cited 2017 Aug 06];23(5):1130-8. Available from: http://www.scielo.br/pdf/rlae/v23n6/pt_0104-1169rlae-23-06-01130.pdf

5. Pagliosa $\mathrm{LC}$, Renosto A. Effects of a health promotion and fall prevention program in elderly individuals participating in interaction groups. Fisioter Mov [Internet]. 2014 [cited 2017 May 06];27(1):101-9. Available from: http://www.scielo.br/pdf/fm/v27n1/0103-5150-fm-27-01-0101.pdf

6. Nunes BP, Saes MO, Siqueira FV, Tomasi E, Silva SM, Silveira DS, et al. Falls and self-assessment of eyesight among elderly people: a population-based study in a south Brazilian municipality. Arch Gerontol Geriatr [Internet]. 2014 [cited 2017 Dec 15];59(1):131-5. Available from: https://www.sciencedirect.com/science/article/pii/S016749431400034X

7. Lamenca BS, López SA, Larrea LC, Ferrer CN, Labanda RM. Análisis de las caídas en una residencia de ancianos y de la influencia del entorno. Gerokomos [Internet]. 2016 [cited 2017 Sep 15];27(1):2-7. Available from: http://scielo.isciii.es/pdf/geroko/v27n1/02_originales_01.pdf

8. Araújo Neto AH, Patrício ACFA, Ferreira MAM, Rodrigues BFL, Santos TD, Rodrigues TDB, et al. Falls in institutionalized older adults: risks, consequences and antecedents. Rev Bras Enferm [Internet]. 2017 [cited 2017 Sep 06];70(4):719-25. http://www.scielo.br/pdf/reben/ v70n4/0034-7167-reben-70-04-0719.pdf

9. Dellaroza MSG, Pimenta CAM, Lebrão ML, Duarte YAO, Braga PE. Association between chronic pain and self-reported falls in the SABE study population. Cad Saúde Pública [Internet]. 2014 [cited 2017 Sep 10];30(3):522-32. Available from: http://www.scielo.br/pdf/csp/v30n3/0102311X-csp-30-3-0522.pdf

10. Nascimento JS, Tavares DMS. Prevalência e fatores associados a quedas em idosos. Texto Contexto Enferm [Internet]. 2016 [cited 2017 Sep 11];25(2):e0360015. Available from: http://www.scielo.br/pdf/tce/v25n2/0104-0707-tce-25-02-0360015.pdf

11. Soares WJS, Moraes AS, Ferriolli E, Perracini MR. Factors associated with falls and recurrent falls in elderly: a population-based study. Rev Bras Geriatr Gerontol [Internet]. 2014 [cited 2017 Sep 11];17(1):49-60. Available from: http://www.scielo.br/pdf/rbgg/v17n1/1809-9823rbgg-17-01-00049.pdf

12. Meschial WC, Soares DFPP, Oliveira NLB, Nespollo AM, Silva WA, Santil FLP. Elderly victims of falls seen by prehospital care: gender differences. Rev Bras Epidemiol [Internet]. 2014 [cited 2017 Sep 11];17(1):3-16. Available from: http://www.scielo.br/pdf/rbepid/v17n1/ pt_1415-790X-rbepid-17-01-00003.pdf

13. Chianca TCM, Andrade CR, Albuquerque J, Wenceslau LCC, Tadeu LFR, Macieira TGR, Ercole FF. Prevalence of falls in older adults enrolled in a Health Center of Belo Horizonte-MG. Rev Bras Enferm [Internet]. 2013 [cited 2017 Sep 11];66(2):234-40. Available from: http://www.scielo. $\mathrm{br} / \mathrm{pdf} / \mathrm{reben} / \mathrm{v} 66 \mathrm{n} 2 / 13 . \mathrm{pdf}$

14. Silva JD, Cortez LER. Main external causes of the elderly in urgency and emergency units. Uningá Review [Internet]. 2015 [cited 2017 Sep 11];23(3):38-43. Available from: https://www.mastereditora.com.br/periodico/20150902_110535.pdf

15. Sukumar DW, Harvey LA, Mitchell RJ, Close JCT. The impact of geographical location on trends in hospitalisation rates and outcomes for fall-related injuries in older people. Aust N Z J Public Health. [Internet]. 2016 [cited 2017 Sep 11];40(4):342-8. Available from: https:// onlinelibrary.wiley.com/doi/pdf/10.1111/1753-6405.12524

16. Rodrigues IG, Fraga GP, Barros MBA. Falls in the elderly: risk factors in population-based study. Rev Bras Epidemiol [Internet]. 2014 [cited 2017 Sep 11];17(3):705-18. Available from: http://www.scielo.br/pdf/rbepid/v17n3/pt_1415-790X-rbepid-17-03-00705.pdf

17. Ministério da Saúde (BR). Resolução n 466, de 12 de dezembro de 2012. Diário Oficial da União [Internet]. 2012 [cited 2017 Sep 17]. Available from: http://bvsms.saude.gov.br/bvs/saudelegis/cns/2013/res0466_12_12_2012.html

18. Instituto Brasileiro de Geografia e Estatística. Panorama de Pelotas-RS. Brasília, DF: IBGE; 2010 [cited 2017 Mar 13]. Available from: https:// cidades.ibge.gov.br/brasil/rs/pelotas/panorama

19. Tribess S, Virtuoso Jr JS, Oliveira RJ. Atividade física como preditor da ausência de fragilidade em idosos. Rev Assoc Med Bras [Internet]. 2012 [cited 2017 Sep 17];58(3):341-7. Available from: http://www.scielo.br/pdf/ramb/v58n3/v58n3a15.pdf

20. Organização Mundial da Saúde (OMS). Envelhecimento ativo: uma política de saúde [Internet]. Brasília, DF: Organização Pan-Americana da Saúde; 2005 [cited 2017 Sep 17]. Available from: http://bvsms.saude.gov.br/bvs/publicacoes/envelhecimento_ativo.pdf

21. Carneiro J, Ramos GCF, Barbosa ATF, Vieira EDS, Silva JSR, Caldeira AP. Falls among the non-institutionalized elderly in northern Minas Gerais, Brazil: prevalence and associated factors. Rev Bras Geriatr Gerontol [Internet]. 2016 [cited 2017 Sep 17];19(4):613-25. Available from: http:// www.scielo.br/pdf/rbgg/v19n4/pt_1809-9823-rbgg-19-04-00613.pdf

22. Alves RLT, Moreira e Silva CF, Pimentel LN, Costa IA, Souza ACS, Coelho LAF. Evaluation of risk factors that contribute to falls among the elderly. Rev Bras Geriatr Gerontol [Internet]. 2017 [cited 2017 Sep 17];20(1):59-69. Available from: http://www.scielo.br/pdf/rbgg/v20n1/ pt_1809-9823-rbgg-20-01-00056.pdf

23. Tomita Y, Arima K, Kanagae M, Okabe T, Mizukami S, Nishimura T, et al. Association of physical performance and pain with fear of falling among community - dwelling Japanese women aged 65 years and older. Medicine [Internet]. 2015 [cited 2017 Sep 11];94(35):1-4. Available 
from: https://www.ncbi.nlm.nih.gov/pmc/articles/PMC4616514/pdf/medi-94-e1449.pdf

24. Lo AX, Brown CJ, Sawyer P, Kennedy RE, Allman RM. Life-space mobility declines associated with incident falls and fractures. J Am Geriatr Soc [Internet]. 2014 [cited 2017 Sep 11];62(5):919-23. Available from: https://www.ncbi.nlm.nih.gov/pmc/articles/PMC4049071/

25. Menezes C, Vilaça KHC, Menezes RL. Falls and quality of life of people with cataracts. Rev Bras Oftalmol [Internet]. 2016 [cited 2017 Sep 11];75(1):40-4. Available from: http://www.scielo.br/pdf/rbof/v75n1/0034-7280-rbof-75-01-0040.pdf

26. Heitor SFD, Rodrigues LR, Tavares DMS. Factors associated with metabolic complications and feeding in elderly from the rural area. Cien Saude Colet [Internet]. 2016 [cited 2017 Sep 11];21(11):3357-66. Available from: http://www.redalyc.org/pdf/630/63048304006.pdf

27. Siqueira FV, Facchini LA, Piccini RX, Tomasi E, Thumé E, Silveira DS, et al. Prevalence of falls and associated factors in the elderly. Rev Saúde Pública [Internet]. 2007 [cited 2017 Sep 11];41(5):749-56. Available from: http://www.scielo.br/pdf/rsp/v41n5/6188.pdf

28. Focchesatto A, Rockett FC, Perry IDS. Risk and protective factors for the development of chronic diseases in a rural elderly population in Rio Grande do Sul. Rev Bras Geriatr Gerontol [Internet]. 2015 [cited 2017 Sep 11];18(4):779-95. Available from: http://www.scielo.br/pdf/rbgg/ v18n4/pt_1809-9823-rbgg-18-04-00779.pdf

29. Cruz DT, Cruz FM, Ribeiro AL, Veiga CL, Leite ICG. Association between cognitive ability and the occurrence of falls in elderly. Cad Saúde Colet [Internet]. 2015 [cited 2017 Sep 18];23(4):386-93. Available from: http://www.scielo.br/pdf/cadsc/v23n4/1414-462X-cadsc-23-4-386.pdf

30. Nunes BP, Thumé E, Facchini LA. Multimorbidity in older adults: magnitude and challenges for the Brazilian health system. BMC Public Health [Internet]. 2015 [cited 2017 Sep 11];15:1172. Available from: https://bmcpublichealth.biomedcentral.com/track/pdf/10.1186/ s12889-015-2505-8 